\title{
Zapewnienie bezpieczeństwa energetycznego jako warunku zrównoważonego rozwoju Polski
}

\author{
Ensuring Energy Security as a Condition for Sustainable Development of Poland
}

\author{
Waldemar Jędral \\ Wydział Mechaniczny Energetyki i Lotnictwa, Politechnika Warszawska \\ ORCID: https://www.orcid.org/0000-0003-0970-1906 • wjedral@itc.pw.edu.pl \\ Zgłoszono: 5.03.2020; zrecenzowano: 14.04.2020; zaakceptowano do druku:17.04.2020
}

\begin{abstract}
Streszczenie: Bezpieczeństwo energetyczne jest warunkiem zrównoważonego rozwoju Polski. Celem pracy było omówienie problemów związanych z zapewnieniem bezpieczeństwa energetycznego i przedstawienie racjonalnych sposobów rozwiązania tych problemów. Uzasadniono konieczność znacznego ograniczenia spalania paliw kopalnych, m.in. w celu zmniejszenia emisji wielu szkodliwych substancji. Wskazano na potrzebę funkcjonowania dużych źródeł energii sprawnych, niezawodnych, sterowalnych i stabilnych przez cały rok i przy każdej pogodzie. Oparcie polskiej energetyki na dużych elektrowniach wiatrowych i fotowoltaicznych uniemożliwia osiągnięcie bezpieczeństwa energetycznego, brak bowiem jak dotąd efektywnych metod magazynowania wielkich ilości energii elektrycznej (e.e.). Istotną rolę może za to odegrać masowy rozwój małych, rozproszonych odnawialnych źródeł energii (OZE) wytwarzających e.e. i ciepło na użytek własny i wysyłających nadwyżki e.e. do sieci. Ważnym zasobem energii, wciąż niedostatecznie wykorzystanym, jest potencjał efektywności energetycznej procesów produkcyjnych i eksploatacyjnych. Konieczne jest też ograniczenie marnotrawienia wielkich ilości energii na produkcję wyrobów jednorazowego użytku, nienaprawialnych lub niskiej jakości, albo zbyt często wymienianych na nowe. W pracy zastosowano metodę krytycznej analizy obecnego stanu rzeczy i niewłaściwych rozwiązań wykorzystującą proste oszacowania oparte na informacjach z dostępnej literatury przedmiotu.
\end{abstract}

Słowa kluczowe: bezpieczeństwo energetyczne, odnawialne źródła energii, efektywność energetyczna, energia wbudowana, magazynowanie energii

\begin{abstract}
Energy security is a condition for the sustainable development of Poland. The paper is aimed at discussing problems related to ensuring energy security and presenting rational ways of solving them. The author justifies the need for a significant reduction in the burning of fossil fuels, among others, to reduce the emissions of many harmful substances. The need for efficient, reliable, controllable, and stable energy sources throughout the year, and in any weather has also been highlighted. Basing Polish energy on large wind and solar farms is prevented by the lack of effective methods for storing large amounts of electricity (e.e.). An important role in this respect may be played by massive development of small, distributed RES producing e.e. and heat for personal use and sending surplus e.e. to the network. The energy efficiency potential of production, and the related operating processes, can be considered an important resource. It is also necessary to significantly reduce the wastage of large amounts of energy to produce disposable, non-repairable, or lowquality products. The method used in the paper is a critical analysis of the current situation, along with improper solutions, using simple estimates, based on information from the available literature on the subject.
\end{abstract}

Keywords: energy security, renewable energy sources, energy efficiency, embodied energy, energy storage 


\section{Wprowadzenie}

Istotą zrównoważonego rozwoju jest zaspokojenie potrzeb obecnego pokolenia bez zmniejszania szans przyszłych pokoleń na taki sam rozwój. Jednym z jego celów jest zapewnienie wszystkim dostępu do stabilnych źródeł energii wysokiej jakości i w przystępnej cenie (Agenda 2030 2015, 2-4). Energia, oprócz żywności, czystej wody i czystego powietrza, jest niezbędna do godnej egzystencji wszystkich mieszkańców Ziemi.

Jednym z warunków zrównoważonego rozwoju jest bezpieczeństwo energetyczne, tj. stan gospodarki umożliwiający pokrycie obecnego i perspektywicznego zapotrzebowania na energię i paliwa w sposób technicznie i ekonomicznie uzasadniony. Można je osiągnąć, chroniąc równocześnie środowisko, przez wysokosprawne przetwarzanie i wysyłanie wszystkim odbiorcom dostatecznych ilości dobrej energii oraz jej efektywne wykorzystanie.

System energetyczny powinien dostarczać odbiorcom energię elektryczną (e.e.) nieprzerwanie, niezależnie od pory roku, pogody i niekorzystnych lub nieprzewidzianych wydarzeń. Będzie to łatwiejsze i tańsze, jeśli ograniczy się zapotrzebowanie na energię poprzez:

- znacznie większe niż dotąd wykorzystanie potencjału efektywności energetycznej,

- masowe stosowanie małych, rozproszonych odnawialnych źródeł energii (OZE),

- ograniczenie do minimum marnotrawienia wielkich ilości energii.

Racjonalne zapewnienie bezpieczeństwa energetycznego Polski, bez degradowania środowiska naturalnego, jest bardzo ważne, ale równocześnie bardzo trudne w warunkach nasilającej się, zwłaszcza w Europie, walki ze zmianami klimatycznymi. Jest też zgodne, zdaniem autora, z tezami encykliki Laudato Si', akcentującej odpowiedzialność każdego człowieka wobec Ziemi, uważanej za „wspólny dom”. Różne aspekty tej odpowiedzialności, nie tylko w kwestii klimatu i jego zmian, omawiają autorzy referatów na międzynarodowej konferencji w Warszawie
(Szyszko 2016, 55-65; Chrostowski 2016, 150-156). Niektóre z proponowanych rozwiązań mogą być uznane za dyskusyjne, lecz ich zaniechanie może się okazać dla Polski bardzo kosztowne.

\section{Zmiany klimatu i dwutlenek węgla}

Obserwowany w ostatnich 170 latach wzrost średniej temperatury Ziemi o ok. $1^{\circ} \mathrm{C}$ powoduje narastanie obaw przed skutkami globalnego ocieplenia powszechnie wiązanego ze wzrostem udziału gazów cieplarnianych $\mathrm{w}$ atmosferze. Intergovernmental Panel on Climate Change (IPCC) oraz większość badaczy i polityków twierdzi, że przyczyny zmian klimatu są antropogeniczne i wynikają z rosnącej emisji dwutlenku węgla $\left(\mathrm{CO}_{2}\right)$ towarzyszącej procesom wytwarzania i użytkowania dóbr materialnych. Kolejne raporty IPCC - AR1 1990...AR5 2014 (podsumowane w Ipcc.ch 2019) - mocno stawiające taką tezę, oparte są na wynikach rozwiązań komputerowych bardzo złożonych układów nieliniowych równań różniczkowych cząstkowych, będących tylko modelem matematycznym jeszcze bardziej złożonych zjawisk kształtujących klimat Ziemi. Wyniki obliczeń zależą jednak silnie od dokładności modelu, zwłaszcza od dość arbitralnie przyjmowanych wartości wielu współczynników empirycznych.

Niektórzy badacze, skłaniający się do uznania antropogenicznych przyczyn ocieplenia klimatu, dodają wszakże, iż: „Być może, w sukurs działaniom zmniejszającym emisję gazów cieplarnianych przyjdzie naturalna zdolność ekosystemu do utrzymywania warunków sprzyjających życiu. Można też mieć nadzieję - w tym przypadku opartą na ściślejszych podstawach - że antropogeniczne postępy globalnego ocieplenia zostaną powstrzymane przez naturalny bieg tendencji klimatycznych, które mają przeciwstawny charakter i sprzyjają raczej oziębianiu się klimatu. W dalszej perspektywie czasowej należy liczyć się ze schyłkiem obecnego interglacjału, który w porównaniu z poprzednimi okresami ciepłymi trwa już 
wystarczająco długo" (Kożuchowski 1999, 807).

Teza o przyczynach antropogenicznych jest kwestionowana przez badaczy, m.in. nieformalnie działających w ramach Nongovernmental International Panel on Climate Change (NIPCC), którzy są jednak w mniejszości. Uważają oni, że przyczyny te są naturalne: zmienność energii dostarczanej przez Słońce i - w pewnym stopniu - promieniowanie kosmiczne (Idso et al. 2013, 3-16; Idso et al. 2015, 97-103; Kożuchowski 1999, 807); nie ma dowodów na to, że właśnie działalność człowieka, zwłaszcza antropogeniczna emisja $\mathrm{CO}_{2}$, wpływa na klimat Ziemi (Szymczyk 2004, 24-30; Kngeol.pan.pl 2008; Cowie 2009, XII). Niestety, dopiero za kilkaset (kilka tysięcy?) lat okaże się, która z hipotez była prawdziwa.

Klimat Ziemi nigdy nie był stały i często zmieniał się bardzo znacznie (Oleszczak 2006, 39-48; Macdougall 2008, 15-17; Kożuchowski 19999, 803-804). Wystąpiły np. dwa długotrwałe oziębienia, których konsekwencją była Ziemia prawie całkowicie zamarznięta: „Ziemia Śnieżka” - ok. 2,2 mld i $600 \mathrm{mln}$ lat temu (Cowie 2009, 66-69), naprzemiennie z gwałtownymi ociepleniami. Zaledwie ok. 11600 lat temu z terenów dzisiejszej Polski wycofał się lodowiec z powodu wzrostu temperatury o $5-8^{\circ} \mathrm{C}$ (Cowie 2009, 112-113, 140-141), z całą pewnością niespowodowanego przez człowieka. Także zawartość $\mathrm{CO}_{2} \mathrm{w}$ atmosferze bywała znacznie większa niż obecnie: 5 razy większa ok. 220 mln lat temu i aż 22 razy większa 420 mln lat temu (Oleszczak 2006, 39; Cowie 2009, 416). Wydaje się więc, że zamiast walczyć ze zmianami klimatu lepiej jest, znacznie skuteczniej niż dotąd, dostosowywać się do nich przez racjonalne działania, na przykład przez budowę dużych zbiorników retencyjnych/przeciwpowodziowych oraz odbudowę małej retencji, którą wspomagają mikroelektrownie wodne, zbiorniki w lasach, a także nieosuszane bagna i torfowiska.

\section{Paliwa kopalne a ochrona klimatu}

Spalanie paliw kopalnych: gazu ziemnego, pochodnych ropy naftowej i węgla powoduje emisję do atmosfery dużych ilości dwutlenku węgla. Produkcji e.e. w Polsce, opartej w $80 \%$ na spalaniu węgla, towarzyszy emisja $40 \%$ całkowitej ilości wytwarzanego $\mathrm{CO}_{2}$ (Oleszczak 2006, 38) ocenianej na ponad 380 mln ton rocznie (Jeszke i in. 2009, 9; McKinsey\&Company 2009, 6). Niezależnie od tego, czy $\mathrm{CO}_{2}$ wpływa na klimat, należy jednak ograniczać spalanie paliw kopalnych. Jest to konieczne zwłaszcza po to, aby zmniejszyć emisję towarzyszących temu innych, naprawdę szkodliwych substancji: pyłów, popiołów, tlenków siarki i azotu, pierwiastków ciężkich, w tym także izotopów promieniotwórczych. Ponadto:

- powoli wyczerpują się zasoby paliw, zwłaszcza łatwo dostępne i rosną koszty ich wydobycia, co będzie niebawem jednym z powodów znacznego wzrostu cen e.e.,

- niezbędne jest wydatne zmniejszenie emisji $\mathrm{CO}_{2}$, aby uniknąć dalszego wzrostu cen energii spowodowanego mocno rosnącymi na aukcjach cenami uprawnień do emisji,

- lepiej jest wykorzystywać paliwa jako surowce dla przemysłu, niż je po prostu spalać,

- należy pozostawić następnym pokoleniom wystarczające zasoby wartościowych surowców zamiast tylko zdegradowanego środowiska naturalnego.

Trzeba zatem eliminować najstarsze elektrownie z niskosprawnymi blokami $200 \mathrm{MW}$ i mniejszymi oraz modernizować przemysł ciężki. Nie da się tego jednak zrobić w ciągu roku lub dwóch. Powstaje też zasadnicze pytanie: czy można całkowicie zrezygnować ze spalania węgla? Albo jeszcze ściślej: czy można w Polsce, w przewidywalnej perspektywie czasowej, całkowicie wyeliminować węgiel, nie budując równocześnie elektrowni jądrowych, natomiast opierając produkcję e.e. tylko na odnawialnych źródłach energii? 


\section{Konieczność posiadania dużych, stabilnych i niezawodnych źródeł energii}

W najbliższych latach powinno się stosunkowo szybko i kosztem dużych nakładów finansowych zmieniać model polskiej energetyki, rozwiązując równocześnie problem sprawnego i niezawodnego przesyłu energii. Trzeba też mocno ograniczać spalanie w transporcie i paleniskach domowych w ramach walki o czyste powietrze i likwidację smogu. Należy pamiętać, że duże aglomeracje miejskie, ważne okręgi przemysłowe, trakcja elektryczna, stacje ładowania samochodów elektrycznych oraz kluczowe obiekty użyteczności publicznej wymagają niezawodnych, stabilnych i sterowalnych źródeł energii. Podkreśla się, że w 2050 r. aż 80\% ludzkości będzie żyło w wielkich aglomeracjach (Chmielewski i Smoliński 2015, 12), które powinny korzystać z takich właśnie źródeł. Już więc teraz trzeba odnieść się do wielu ważnych kwestii, podejmując niezwłocznie działania stosowne do proponowanych, najbardziej racjonalnych odpowiedzi na pytania:

- jak szybko i szeroko rozwijać OZE, ograniczając równocześnie energetykę węglową?

- czy rozwijać duże, scentralizowane OZE (np. farmy wiatrowe), czy rozproszone (na potrzeby indywidualne i zbiorowe) i rozsiane (na potrzeby gospodarstw domowych)?

- w jaki sposób magazynować wielkie ilości e.e. produkowane przez OZE?

- jak duży powinien być udział w produkcji e.e. wysokosprawnych źródeł stabilnych, sterowalnych, zdolnych do pracy przez cały rok i przy każdej pogodzie?

- jakiego rodzaju powinny być te źródła: elektrownie węglowe, gazowe czy (i) jądrowe?

Wydaje się z jednej strony, że wobec postulowanej zerowej emisji $\mathrm{CO}_{2} \mathrm{w}$ Unii Europejskiej (UE) w $2050 \mathrm{r}$. i rosnących cen uprawnień do emisji nabywanych na giełdach, mało realne jest uniknięcie konieczności budowy kilku elektrowni jądrowych o łącznej mocy rzędu co najmniej 8 ...12 GW.
Z drugiej strony trzeba przestać marnotrawić wielkie ilości energii i znacznie bardziej racjonalnie ją wykorzystywać, powiększając efektywność energetyczną procesów produkcyjnych i eksploatacyjnych, także w użytkowaniu energii przez najmniejszych jej odbiorców. Równocześnie należy jednak rozsądnie inwestować także w źródła odnawialne - OZE.

\section{Duże źródła OZE - farmy wiatrowe}

Postulat walki ze zmianami klimatu jest już realizowany w Polsce poprzez budowę coraz większych farm wiatrowych na lądzie (on shore) i zaawansowane przygotowania do ich budowy na Bałtyku (off shore). Największa aktualnie w Polsce farma lądowa ma moc zainstalowaną $120 \mathrm{MW}$, planowana zaś - 6oo MW, natomiast na Bałtyku przewiduje się budowę farm o mocy od 6 do 20 GW, przy potencjale sięgającym $35 \mathrm{GW}$ (Wiśniewski i in. 2012, 5) i produkcji e.e. rzędu co najmniej 15 TWh rocznie. Przewiduje się uruchomienie pierwszej farmy morskiej w 2025 r. (PEP 2040 2019, 54).

Zaletą farm wiatrowych jest brak emisji szkodliwych zanieczyszczeń i $\mathrm{CO}_{2}$ oraz zerowe koszty paliwa podczas eksploatacji . Ale duże farmy wiatrowe mają też poważne wady:

- współczynnik $c_{\mathrm{f}}$ wykorzystania mocy zainstalowanej, z powodu małych średnich prędkości wiatru w Polsce $(2,8 \mathrm{~m} / \mathrm{s}$ w lecie oraz $3,8 \mathrm{~m} / \mathrm{s} \mathrm{w}$ zimie), wynosi zaledwie (EWEA 2010, 41; Wiśniewski i in. 2012, 23; Chronmyklimat.pl 2012):

* na lądzie $c_{\mathrm{f}}=0,2 \ldots 0,25$; dla $2018 \mathrm{r}$. autor oszacował $c_{\mathrm{f}}=0,206$, na podstawie (Pse.pl 2018, 5, 30);

* na Bałtyku $c_{\mathrm{f}}=0,30 \ldots ., 35(0,40)$;

- wskutek tego elektrowni węglowej o mocy $1000 \mathrm{MW}$ odpowiada elektrownia wiatrowa o mocy zainstalowanej $3300 \mathrm{MW}$ na lądzie i $2200 \mathrm{MW}$ na Bałtyku,

- powierzchnia zajęta przez farmy wiatrowe jest wielokrotnie większa niż w przypadku elektrowni jądrowych i węglowych; budowana w USA 
największa na świecie farma wiatrowa o mocy $800 \times 2,5=2000 \mathrm{MW}$ ma zająć powierzchnię $1214 \mathrm{~km}^{2}$ (Kierunekenergetyka.pl 2018); oszacowano (Jędral 2019, 4-5), że gdyby wszystkie polskie elektrownie spalające paliwa kopalne zastąpić dużymi farmami wiatrowymi, to zajęłyby one powierzchnię rzędu $1 / 5 \ldots 1 / 4$ całej powierzchni Polski,

- duże (o mocy pojedynczej turbiny $\geq 1,5$ MW) elektrownie wiatrowe mają bardzo duże rozmiary i wielką masę; energię wbudowaną, zużytą na wytworzenie, fundamentowanie i montaż takich zespołów można ocenić na 5-6-krotność produkowanej przez nie e.e. w roku (Fernando and Bodger 2010, 778-779),

- elektrownie wiatrowe są awaryjne - odnotowano dotychczas stosunkowo dużo awarii, niekiedy bardzo poważnych, oraz ofiary śmiertelne (Malnick and Mendick 2011). Często mówi się także o zagrożeniach dla zdrowia ludzi i życia zwierząt, zwłaszcza ptaków, nietoperzy i owadów (Strupczewski i Koszuk 2019a, 149-150).

\section{Duże źródła OZE - elektrownie fotowoltaiczne}

Zalety elektrowni słonecznych to nie tylko brak emisji szkodliwych produktów spalania i emisji $\mathrm{CO}_{2}$ oraz kosztów paliwa, nie oddziałują one też ujemnie na ludzi i środowisko podczas eksploatacji. W warunkach polskich do produkcji e.e. na większą skalę nie nadają się jednak kolektory słoneczne (zbyt małe nasłonecznienie), za to można i warto je masowo stosować w małych instalacjach domowych do ciepłej wody użytkowej. Jedyną możliwość wytwarzania na większą skalę e.e. dają elektrownie zbudowane $\mathrm{z}$ paneli fotowoltaicznych.

Elektrownie fotowoltaiczne (EPV) zajmują mniejsze powierzchnie niż wiatrowe, mają za to jeszcze niższy współczynnik wykorzystania mocy zainstalowanej (tj. maksymalnej możliwej), rzędu tylko o,1 (Strupczewski i Koszuk 2019a, 163). Moc chwilowa osiągalna dla Polski, to ok. $1000 \mathrm{~W} / \mathrm{m}^{2}$, moce średnio dobowe zaś wahają się od $20 \mathrm{~W} / \mathrm{m}^{2}$ w pochmurny dzień w grudniu do $325 \mathrm{~W} / \mathrm{m}^{2}$ w bezchmurny dzień w czerwcu (Chodura 2013, 48); dochodzi do tego duża rozpiętość dobowa (o - noc, max - dzień). Dlatego EPV wymagają jeszcze skuteczniejszego magazynowania energii niż farmy wiatrowe. Mimo to przewiduje się budowę w Polsce coraz większych EPV, np. o mocy $600 \mathrm{MW}$ w Wielkopolsce (Przemyski 2019, 99).

Możliwość osiągania największych mocy w upalne, bezchmurne dni można by ewentualnie wykorzystać wówczas, kiedy masowo włączane klimatyzatory powodują poważne przeciążenie systemu elektroenergetycznego i niedobory mocy (20. stopień zasilania 10 sierpnia 2015 r.). EPV mogłyby skutecznie wspomagać system, produkując właśnie wtedy najwięcej energii. Wykorzystanie EPV jako źródeł szczytowych w lecie wymagałoby jednak uzasadnienia rzetelnie wykonanym rachunkiem kosztów.

Elektrownie wiatrowe i fotowoltaiczne to praktycznie jedyne duże OZE, które można budować i eksploatować w Polsce. Całkowite jednak zastąpienie nimi elektrowni węglowych, przy dużych sprzeciwach rozmaitych organizacji ekologicznych dotyczących budowy elektrowni jądrowych, spowodowałoby ogromne zagrożenia dla całej gospodarki, uniemożliwiając zrównoważony rozwój kraju. Inne OZE - woda i biopaliwa - mają w Polsce małe znaczenie, kwestionowana jest ponadto celowość wykorzystania niektórych z nich (Jędral 2019, 5-6). Należy dodać, że warunki do rozwoju dużych OZE w Polsce są o wiele gorsze niż w innych państwach Europy. W Belgii, Danii, Holandii i w Niemczech farmy wiatrowe off-shore stawia się na Morzu Północnym, gdzie warunki wietrzne są znacznie lepsze niż na Bałtyku. W Hiszpanii, Portugalii czy na południu Francji dużo większe nasłonecznienie sprzyja budowie farm EPV i innego typu elektrowni słonecznych, warunki hydrogeologiczne zaś w Szwajcarii, Austrii i zwłaszcza Norwegii sprzyjają budowie dużych elektrowni wodnych. 


\section{Problem magazynowania energii}

Niezależnie od zbyt dużych powierzchni zajmowanych przez farmy wiatrowe i EPV podstawowa pozostaje kwestia magazynowania e.e. wytwarzanej przez nie w nadmiarze, gdy mocno wieje, aby korzystać z niej wtedy, kiedy energii jest zbyt mało. Bardzo duży problem stanowią 4-5-dniowe okresy ciszy, kiedy stają elektrownie wiatrowe w całej Europie; zdarzają się one co najmniej 1-2 razy w roku (Strupczewski i Koszuk 2019b, 77). Natomiast wówczas, gdy wieje bardzo silnie, produkcja e.e. może znacznie przekraczać zapotrzebowanie. Ze względu na nieprzewidywalną i niesterowalną pracę elektrowni wiatrowych oraz możliwe dłuższe przerwy ich pracy, konieczne jest budowanie magazynów energii i wspomagających elektrowni, najlepiej gazowych (zapewniających prawie natychmiastowy rozruch). Brakuje jednak dotąd skutecznego sposobu magazynowania wielkich ilości e.e.; nie są to baterie elektryczne ani elektrownie pompowe, których rozładowanie trwa zwykle $4 . . .6$ godzin.

Obecnie możliwe sposoby magazynowania energii są w warunkach polskich dalece niewystarczające i niezmiernie kosztowne. Oszacowano, że gdyby $20 \%$ ze 165 TWh e.e. w Polsce w 2018 r. wyprodukowały farmy wiatrowe, to cisza trwająca 100 godzin spowodowałaby brak w systemie ok. 377 GWh (Jędral 2019, 6), podczas gdy elektrownie pompowe i zbiornikowe moga zmagazynować tylko ok. 8 GWh (Strupczewski i Koszuk 2019b, 79). Brak pozostałych 98\% zapotrzebowania spowodowałby ogromne perturbacje w funkcjonowaniu kraju. Elektrochemiczne zmagazynowanie brakującej ilości e.e. wymagałoby budowy magazynów zawierających ponad 4,4 mln akumulatorów litowo-jonowych Tesli (pojemność każdego to obecnie $85 \mathrm{kWh}$ ); zakładając, że cena 1 kWh w takim akumulatorze spadnie z aktualnych ok. 200 USD do 73 USD (Strupczewski i Koszuk 2019b, 82), koszt samych akumulatorów byłby rzędu 112 mld zł.

Nawet brak wiatru tylko przez 10 godzin byłby bardzo kłopotliwy. Cisza trwająca w tym czasie w całej Europie skutkowałaby bowiem brakiem możliwości sprowadzenia e.e. z zewnątrz. Gdyby farmy wiatrowe produkowały jeszcze więcej, bo połowę całej ilości e.e. wytwarzanej w Polsce, taka przerwa byłaby prawdziwą katastrofą.

Dodatkowo, podnoszona jest kwestia negatywnego wpływu na środowisko masowej produkcji baterii elektrycznych i ich późniejszego złomowania, zwłaszcza ogromnego zużycia wody do produkcji litu oraz skażenia wody i gleby (Strupczewski i Koszuk 2019b, 82). Do czasu, kiedy zostanie rozwiązany problem skutecznego i wysokosprawnego magazynowania wielkich ilości energii, e.e. otrzymywana $\mathrm{z}$ farm wiatrowych i elektrowni EPV powinna być raczej tylko stosunkowo niewielkim uzupełnieniem energii ze źródeł stabilnych i sterowalnych, łatwo dostosowujących swoją produkcję do bieżącego zapotrzebowania.

\section{Potencjał efektywności energetycznej}

Wciąż zbyt mało wykorzystywanym zasobem energii jest efektywność energetyczna gospodarowania, tj. wszelkich procesów produkcyjnych i eksploatacyjnych w całej gospodarce narodowej (Jędral 2011, 90-95; Jędral 2018, 245-254). Najbardziej ogólna jej definicja: efektywność energetyczna $=E / W$, gdzie $W$ jest ilością energii (wkładem) potrzebnej do uzyskania efektu użytkowego $E$ (PEP 2040 2019, 63), np. ilości wyprodukowanego cementu, ciepła, e.e. itp. Zasób ten jest często nazywany czwartym paliwem.

Zużycie e.e. do wytworzenia 1 jednostki PKB w Polsce jest wciąż jeszcze od 1,3 do 1,5 razy większe niż w rozwiniętych państwach UE (np. Cebrat 2014, 63-64), toteż krajowy potencjał efektywności energetycznej ocenia się na co najmniej $30 \mathrm{TWh}$ rocznie (McKinsey\&Company 2009, 13). Oznacza to, że można by wyeliminować z eksploatacji wiele starych bloków węglowych produkujących taką właśnie ilość e.e. Oszczędność energii, uniknięcie emisji znacznych ilości $\mathrm{CO}_{2}$ i zmniejszenie kosztów e.e. dla użytkowników to podstawowe korzyści ze zwiększenia efektywności energetycznej procesów produkcyjnych i eksploatacyjnych. 
Przewidywany wzrost zapotrzebowania na e.e., rosnącego w Polsce o ok. 1,5\% rocznie, można zaspokoić albo budując nowe źródła energii, albo powiększając efektywność energetyczną gospodarowania poprzez racjonalne modernizacje. Dodatkowe zalety tego drugiego sposobu, w porównaniu z pierwszym, to (Jędral 2018, 254-255):

- znacznie mniejsze koszty realizacji, nawet bardzo dużych modernizacji,

- dużo krótszy okres zwrotu kosztów modernizacji niż kosztu budowy nowego źródła,

- uniknięcie kosztów związanych z zakupem terenów, budową/rozbudową infrastruktury (np. dróg dojazdowych), przyłączeniem do sieci (stacje transformatorów) itp.,

- eliminacja kosztów eksploatacyjnych (zatrudnienia, paliw, napraw i remontów itp.),

- ograniczenie strat energii w sieciach przesyłowych przez zmniejszenie zużycia e.e.,

- obniżenie kosztów emisji $\mathrm{CO}_{2}$,

- brak dodatkowej emisji do atmosfery szkodliwych produktów spalania.

Z tych właśnie powodów należy znacznie bardziej intensywnie, niż obecnie, wykorzystywać istniejący, bardzo duży potencjał efektywności energetycznej przez:

- podwyższanie sprawności procesów wytwarzania e.e. (wycofanie i/lub zastąpienie bloków o mocach $\leq 200 \mathrm{MW}$ wysokosprawnymi blokami o mocach rzędu $1000 \mathrm{MW}$ ),

- powszechnie realizowane modernizacje w energetyce, przemyśle i całej gospodarce (Łazicki 2011, 8-9),

- intensyfikację finansowego wspierania modernizacji przez państwo (Koc 2019, 22),

- masowo wykonywane termomodernizacje; energooszczędne oświetlenie oraz smart grids, smart buildings, smart cities, elektrownie wirtualne (Bielecki $2017,20-23)$ i inne podobne działania niekonwencjonalne.

\section{Energia wbudowana i marnotrawienie energii a emisja $\mathrm{CO}_{2}$}

Większość wyprodukowanej e.e. i ciepła zużywa się w procesach wytwórczych w przemyśle, budownictwie i rolnictwie. Energia potrzebna do wyprodukowania wyrobów (samochodów, lodówek, laptopów, smartfonów itp.) to energia wbudowana (embodied energy). Dane dotyczące poszczególnych wyrobów są dość skąpe. Można jednak ocenić, że np. do wytworzenia średniej wielkości samochodu zużywa się 27800 kWh (Smil 2016, 26; Friedley 2015). W 2015 r. wyprodukowano na świecie $72 \mathrm{mln}$ samochodów; energia wbudowana w nie była rzędu 2000 TWh (12 razy więcej od całej ilości e.e. wytworzonej w Polsce). Połowę tej ilości można by zaoszczędzić, zmniejszając równocześnie emisję $\mathrm{CO}_{2}$ o $900 \mathrm{mln}$ ton/rok, gdyby dwukrotnie wydłużyć okres eksploatacji samochodów w pełni sprawnych technicznie. Wiele e.e. można by zaoszczędzić, wydłużając czas eksploatacji wyrobów elektronicznych i nie wymieniając ich co roku na nowe, modniejsze modele; w 2015 r. zużyto ok. 280 TWh energii elektrycznej do produkcji laptopów, tabletów i telefonów komórkowych (Smil 2016, 26).

Wielki potencjał oszczędności energii ma budownictwo. Ocenia się, że ok. 40\% globalnej ilości $\mathrm{CO}_{2}$ emituje się podczas produkcji materiałów budowlanych, wznoszenia i użytkowania budynków (Joniec 2019, 18); znaczne ilości energii można zaoszczędzić w rolnictwie. Przykłady marnotrawienia energii powodujące konieczność jej nadmiernych dostaw to:

- produkcja wyrobów jednorazowego użytku, które masowo wyrzucane zaśmiecają i degradują środowisko (np. ogromne ilości plastików, dryfujące później w oceanach),

- produkcja wyrobów nienaprawialnych i takich, których nie opłaca się naprawiać, bo taniej jest kupić nowy wyrób,

- produkcja wyrobów niskiej jakości i nietrwałych (ze względu na niski poziom techniczny i ograniczoną świadomość wytwórców), 
- nagminne wytwarzanie wyrobów, zwłaszcza AGD, które dziwnym trafem psują się kilka dni po upływie terminu gwarancyjnego (zwykle po 2 latach),

- produkcja wyrobów niepotrzebnych, kupowanych wskutek natrętnej reklamy,

- zachęcanie (moda + reklama) do ciągłej wymiany dobrych jakościowo i jeszcze sprawnych wyrobów na coraz to nowe: samochody, telefony komórkowe, telewizory, odzież itd.,

- niefrasobliwe marnotrawienie żywności, przy równocześnie panującym głodzie w wielu krajach; powszechnie uważa się, że trzecia część produkowanej na świecie żywności jest marnowana.

Ograniczając powszechne marnotrawienie energii i powiększając efektywność energetyczną gospodarowania, można poważnie zredukować globalne zapotrzebowanie na energię i obniżyć emisję $\mathrm{CO}_{2}$ bardziej, niż rezygnując ze spalania paliw kopalnych. Znacznie jednak łatwiej jest wywrzeć skuteczną presję na rządy państw, aby radykalnie ograniczyły, a nawet całkowicie zlikwidowały emisję $\mathrm{CO}_{2}$, niż na wielkie koncerny, aby ograniczyły zyski. W UE rozpoczęto wprawdzie prace nad rozwiązaniem tego problemu, ale potrwają one zapewne wiele lat. W styczniu 2019 r. Komisja Europejska (KE) przyjęła wstępne założenia przepisów, które mają zmusić producentów, aby sprzedawane przez nich produkty nie psuły się po kilku latach, a jeśli już, to by opłacało się je naprawiać. Plany nowej dyrektywy UE kwestionują jednak producenci, twierdząc, że zaproponowane przepisy dotyczące napraw są zbyt restrykcyjne i będą hamować innowacje (Toborek 2019, 7).

\section{Znaczenie małych OZE}

W przeciwieństwie do dużych źródeł odnawialnych wielką rolę może odegrać masowy rozwój małych, rozproszonych i rozsianych OZE wytwarzających e.e. i/lub ciepło na użytek własny i grupowy, ewentualnie wysyłających nadwyżkę e.e. do sieci. Są to:

- kolektory słoneczne do podgrzewania ciepłej wody użytkowej,
- panele fotowoltaiczne do produkcji niewielkich ilości e.e.,

- małe turbinki wiatrowe po produkcji e.e. i/lub do tłoczenia wody do zbiorników, magazynujących wodę na własne potrzeby lub wspomagających hydrofory,

- małe piece spalające odpady drewna i pelety,

- pompy ciepła, „wyciągające” ciepło z ziemi, wody lub powietrza,

- (na większą skalę) instalacje geotermalne, zaopatrujące w ciepło większe grupy mieszkańców osiedli czy gmin.

Rozwój ten powinien być mądrze wspierany przez państwo. W Polsce funkcjonują już pewne mechanizmy wsparcia (PEP 2040 $2019,56)$, ale warto je dalej rozwijać, zwłaszcza przez bardziej atrakcyjne niż obecnie sposoby dofinansowań.

Odrębną, ważną rolę mogą odegrać małe elektrownie wodne (MEW). Przed 1939 r. w Polsce funkcjonowało ok. 8100 różnych siłowni wodnych (młyny, tartaki, MEW). Podczas drugiej wojny światowej i zwłaszcza w latach 1945-1954 zniszczono blisko 95\% tych obiektów. To, wraz ze źle prowadzonymi melioracjami, osuszaniem bagnisk i torfowisk oraz „regulacją” (prostowaniem biegu) rzek przyczyniło się do spadku poziomu wód gruntowych i stepowienia klimatu, m.in. w Wielkopolsce (Igliński i Skrzatek 2019, 46-48). Małą retencję wodną można w dużym stopniu przywrócić przez budowę wielu MEW o mocach kilkudziesięciu, a nawet tylko kilkunastu kW. Będą one produkowały niezbyt wielkie ilości e.e., natomiast przyczynią się w znacznym stopniu do zwiększenia zasobów wodnych w glebie i likwidacji skutków susz, powtarzających się w ostatnich latach w Polsce coraz częściej.

\section{Elektrownie jądrowe jako alternatywne źródła energii elektrycznej}

Od czasu przerwania w 1990 r. budowy elektrowni jądrowej (e.j.) w Żarnowcu w Polsce wciąż trwają dyskusje na temat celowości budowy nowoczesnych e.j. III, a później IV generacji. Zdaniem autora decyzję 
o rozpoczęciu budowy należy podjąć jak najszybciej. Elektrownie tego typu zapewniają stabilność wytwarzania e.e. przy zerowej emisji zanieczyszczeń powietrza. Ich żywotność przekracza o co najmniej 20 lat żywotność bloków węglowych i gazowych (PEP 2040 2019, 49). Średni współczynnik wykorzystania mocy reaktorów pracujących w USA przekroczył już wartość $c_{\mathrm{f}}=0,90$ (Strupczewski i Koszuk 2019a, 145), czterokrotnie większą od odpowiedniej wartości dla farmy wiatrowej na lądzie i ponaddwukrotnie większą niż dla farmy na Bałtyku. Jednostkowe nakłady inwestycyjne, na $1 \mathrm{~kW}$ średniej mocy e.j. są o ok. 20\% niższe niż dla farmy wiatrowej; ponadto znacznie mniejsze są koszty współpracy e.j. z systemem elektroenergetycznym; są one tym większe, im większy jest udział OZE w systemie. Jeszcze korzystniej wypada porównanie e.j. z farmą EPV (Strupczewski i Koszuk 2019a, 163).

W państwach, które jakiś czas temu zdecydowały się na rezygnację z e.j., zaczęto ostatnio odchodzić od tych decyzji. Obecnie na świecie realizuje się 50 nowych projektów (PEP 2040 2019, 49) w Europie, na Półwyspie Arabskim i w USA. W latach 2033-2043 planuje się uruchomienie w Polsce sześciu bloków jądrowych; właśnie wtedy wystąpią znaczne ubytki mocy wynikające z wyeksploatowania najstarszych bloków węglowych (PEP 2040 2019, 49). Prognozuje się, że od 2020 r. zaczną rosnąć niedobory wymaganej nadwyżki mocy, od $2000 \mathrm{MW}$ do 20 ooo MW w 2035 r. Począwszy od 2021 r. zacznie brakować możliwości pokrycia zapotrzebowania przez elektrownie krajowe (Prognoza PSE, 7). Nowe e.j. pozwolą też na znaczne ograniczenie krajowej emisji gazów cieplarnianych i poważnych zanieczyszczeń powietrza.

Według PEP 2040, w perspektywie co najmniej kilkunastu najbliższych lat nie jest możliwe zapewnienie bezpieczeństwa dostaw energii $\mathrm{w}$ bilansie $\mathrm{z}$ dominującą pozycją OZE, ze względu na zbyt niski stan rozwoju tych technologii i elastyczność pracy systemu elektroenergetycznego. Natomiast budowa bloków jądrowych oraz składowisk odpadów promieniotwórczych pozytywnie oddziałuje na regiony, w których są zlokalizowane, poprzez zwiększenie liczby miejsc pracy - zarówno w elektrowni, jak i w jej otoczeniu, znaczące zwiększenie podatków lokalnych, a także rozwój infrastruktury komunikacyjnej i hydrotechnicznej, co będzie się przekładało na atrakcyjność gospodarczą okolicznych terenów oraz poprawę lokalnych warunków życie (PEP 20402019 , 49-50).

\section{Podsumowanie}

Zrównoważony rozwój Polski jest możliwy pod warunkiem zapewnienia jej bezpieczeństwa energetycznego. W celu zmniejszenia emisji wielu szkodliwych zanieczyszczeń oraz uniknięcia wysokich opłat za emisje $\mathrm{CO}_{2}$ powinno się ograniczyć do minimum, choć nie do zera, spalanie paliw kopalnych; także w transporcie i w paleniskach domowych.

Bezpieczeństwo energetyczne kraju wymaga funkcjonowania pewnej liczby dużych, wysokosprawnych elektrowni węglowych i jądrowych - stabilnych, sterowalnych, niezawodnie pracujących bez względu na pogodę i porę roku. Dopóki nie zostanie skutecznie rozwiązany problem wysokosprawnego i taniego magazynowania wielkich ilości energii elektrycznej, nie można w Polsce zapewnić bezpieczeństwa energetycznego, tylko budując i eksploatując setki wielkich farm wiatrowych i elektrowni fotowoltaicznych. Trzeba natomiast dążyć do masowego stosowania małych OZE przez szerokie rzesze użytkowników indywidualnych i grupowych.

Znacznie intensywniej trzeba wykorzystywać zasoby efektywności energetycznej najszybszy i najtańszy sposób zaspokojenia wzrostu zapotrzebowania na energię, lub wręcz na zmniejszenie tego zapotrzebowania. Zapotrzebowanie na energię, zwłaszcza elektryczną, można dodatkowo znacznie zmniejszyć, eliminując jej powszechne marnotrawienie, m.in. przeciwstawiając się standardom konsumpcji narzucanym przez wielkie korporacje międzynarodowe. Trzeba 
też znacznie zintensyfikować gospodarkę obiegu zamkniętego (w tym recykling).

Zamiast walczyć, jak dotąd nieskutecznie, ze zmianami klimatycznymi, lepiej ogromne środki, jakie ta walka pochłania, przeznaczyć na zdrowie, walkę z ubóstwem, likwidację głodu i braku wody pitnej. Należy też znacznie skuteczniej przeciwdziałać skutkom zmian klimatycznych: powodziom, stepowieniu klimatu Polski i degradacji gleb.

\section{Bibliografia}

Agenda 2030 na rzecz zrównoważonego rozwoju implementacja w Polsce. Cele zrównoważonego rozwoju. 2015. Warszawa: Ministerstwo Rozwoju.

Bielecki, Sławomir. 2017. „Magazyny energii i wirtualne elektrownie - rozwiązania na problemy niestabilnej generacji energii elektrycznej." Energetyka Wodna 2: 18-23.

Cebrat, Krzysztof. 2014. „Wskaźnik energii wbudowanej w pieniądz - drugie spojrzenie na koszty budowy." Rynek Instalacyjny 3: 63-66.

Chmielewski, Andrzej G., i Tomasz Smoliński. 2015. „Polityka energetyczna wybranych krajów Europy, rola energetyki jądrowej." Instal 2: 12-18.

Chodura, Jerzy. 2013. „Promieniowanie słoneczne - podstawowe wiadomości." Rynek Instalacyjny 6: 47-49.

Chrostowski, Waldemar. 2016. „Dar Ziemi i rola edukacji w zrównoważonym rozwoju w świetle encykliki Laudatio Si'” W Zrównoważony rozwój w świetle encykliki Laudatio Si', red. Ewa Kwiecień, 150-156. Toruń: Lux Veritatis.

Colbert, Bruce. 2017. „Climate Change.” Policy Brief February 2, 2017. Los Angeles: Property Owners Association of Riverside County.

Cowie, Jonathan. 2009. Zmiany klimatyczne. Przyczyny, przebieg i skutki dla człowieka. Warszawa: Wydawnictwo Uniwersytetu Warszawskiego.

EWEA (European Wind Energy Association). 2010. Powering Europe: Wind Energy and the Electricity Grid. Brussels: European Wind Energy Association. Accessed May 24, 2020. https://windeurope. org/fileadmin/ewea_documents/documents/publications/reports/Grids_Report_2010.pdf.

Fernando, Deshan, and Pat Bodger. 2010. "Embodied energy analysis of New Zealand power generation systems." In Proceedings of the Second IASTED International Conference Environmental
Management and Engineering, 773-780. Banff: ACTA Press.

Fridley, David. 2015. How much energy does it take to make a car? Accessed May 26, 2019. http:// energyskeptic.com./2015/how-much-energy-doesit-take-to-make-a-car-by-david-fridley-Ibl/.

Idso, Craig D., Robert M. Carter, and Fred S. Singer. 2013. Climate Change Reconsidered II. Physical Science. Summary for Policymakers. 2013 Report of the NIPCC. Chicago: The Hartland Institute.

Idso, Craig D., Robert M. Carter, and Fred S. Singer. 2015. Why Scientists Disagree about Global Warming. The NIPCC Report on Scientific Consensus. Chicago: The Hartland Institute.

Igliński, Bartłomiej, i Mateusz Skrzatek. 2019. „Czy mała energetyka wodna pozwoli na zatrzymanie stepowienia Wielkopolski?" Energetyka Wodna 1: 46-48.

Ipcc.ch. 2019. Climat Change and Land. An IPCC Special Report on climate change, desertification, lend degradation, sustainable land management, food security and greenhouse gas... Accessed January 7 , 2020. https://ipcc.ch/site/asseets/unloads/2019/11/ SRCCL-Full-Report-Compiled-191128.pdf.

Jeszke, Robert, Andrzej Błachowicz, Eugeniusz Smol, Przemysław Sikora, Sebastian Lizak, i Maciej Pyrka. 2009. Wybrane aspekty wdrożenia pakietu energetyczno-klimatycznego (Dyrektywa EUETS i Decyzja NON-ETS). Warszawa: KASHUE-KOBIZE. Jędral, Waldemar. 2011. „Efektywność energetyczna jako ważny zasób energetyczny - porównanie z wybranymi źródłami energii." Rynek Energii 4: 90-96.

Jędral, Waldemar. 2018. Efektywne energetycznie uktady pompowe. Cz. 2. Warszawa: Oficyna Wydawnicza Politechniki Warszawskiej.

Jędral, Waldemar. 2019. „OZE i efektywność energetyczna w kontekście wyzwań dla wytwarzania energii elektrycznej w Polsce." Rynek Energii 5: 3-8. Joniec, Waldemar. 2019. „Budownictwo w obiegu zamkniętym." Rynek Instalacyjny 6: 18.

Kierunekenergetyka.pl. 2018. Powstanie największa farma wiatrowa świata. Dostęp 10.04.2018. https:// www.kierunekenergetyka.pl/artykuły,291.html.

Kngeol.pan.pl. 2009. Stanowisko Komitetu Geologicznego Polskiej Akademii Nauk w sprawie zagrożenia globalnym ociepleniem. Warszawa - Wrocław, luty 2009. Dostęp 15.11.2019. www.kngeol.pan.pl. 
Koc, Dariusz. 2019. „Białe certyfikaty - analiza skutków funkcjonowania systemu i możliwości zmniejszenia kosztów społecznych jego funkcjonowania w 2019 r." Rynek Instalacyjny 5: 19-22.

Kożuchowski, Kazimierz. 1999. „Zmiany i zmienność klimatu." W Encyklopedia Powszechna t. 7 (Suplement), 802-807. Warszawa: PWN.

Łazicki, Artur. 2011. „Ograniczenie energochłonności typowych instalacji i urządzeń przemysłowych - wnioski z audytów oraz prezentacja projektu CARE plus." XVIII Spotkanie Zespotu Merytorycznego Forum Energia - Efekt - Środowisko. Warszawa: NFOŚiGW.

Macdougall, Doug. 2008. Zamarznięta Ziemia. Historia dawnych i przysztych epok lodowcowych. Warszawa: Prószyński i Ska.

Malnick, Edward, i Robert Mendrick. 2011. "1500 accidents and incidents on UK wind farms." The Telegraph, 11 December 2011. https://www.telegraph.co.uk/news/uknews/8948363/1500-accidents-and-incidents-on-UK-wind-farms.html.

Mambiznes.pl. 2012. Farmy morskie tańsze od atomu. Dostęp 8.08.2012. https://mambiznes.pl/wlasny-biznes/wiadomosci/ farmy-morskie-tansze-od-atomu-12667.

McKinsey\&Company. 2009. Ocena potencjatu redukcji emisji gazów cieplarnianych $w$ Polsce do roku 2030. Podsumowanie. Dostęp 24.05.2020. https:// www.cire.pl/pokaz-pdf-\%252Fpliki\%252F2\%252FRaportPodsumowaniePL.pdf.

Oleszczak, Dorota. 2006. Analiza wptywu spalania paliw kopalnych na zawartość dwutlenku węgla w atmosferze. Rozprawa doktorska. Warszawa: Politechnika Warszawska.

PEP 2040. Polityka energetyczna Polski do roku 2040. Projekt. 2019. Warszawa: Ministerstwo Energii. Dostę: 24.05.2020. https://www.gov.pl/attachment/433c2e3f-364d-4845-acc2-2e0239405825.

Przemyski, Jan. 2019. „Ogromna farma solarna powstanie w Polsce." Gazeta Polska 2 października 2019.
Pse.pl. 2018. Raport 2018 KSE. Zestawienie danych ilościowych dotyczacych funkcjonowania KSE w 2018 r. Dostęp 06.05.2019. https://www. pse.pl/dane-systemowe/funkcjonowanie-rb/ raporty-roczne-z-funkcjonowania-kse-za-rok/ raporty-za-rok-2018.

Smil, Vaclav. 2016. „Embodied energy: mobile devices and cars." IEEE Spectrum 53(5): 26. https://doi. org/10.1109/MSPEC.2016.7459114.

Strupczewski, Andrzej, i Łukasz Koszuk. 2019a. „Ekonomiczne aspekty energetyki jądrowej.” Energetyka Cieplna i Zawodowa 5: 143-164.

Strupczewski, Andrzej, i Łukasz Koszuk. 2019b. „Plan B. Czy magazynowanie energii wystarczy do zapewnienia ciągłości zasilania systemu elektroenergetycznego przy dużym udziale odnawialnych źródeł energii?" Energetyka Cieplna i Zawodowa 3: 76-84.

Szymczyk, Józef. 2004. „Problem z gazami cieplarnianymi po III Szczycie Ziemi w Johannesburgu." Rynek Energii 1: 23-31.

Szyszko, Jan. 2016. „Zrównoważony rozwój a polityka klimatyczna w świetle istniejących zagrożeń." W Zrównoważony rozwój w świetle encykliki Laudatio si', red. Ewa Kwiecień, 54-86. Toruń: Lux Veritatis.

Toborek, Piotr. 2019. Gospodarka o obiegu zamkniętym. Bez odpadów i bez złudzeń. Dostęp 21.03.2019. https://www.portalsamorzadowy.pl/gospodarka-komunalna/gospodarka-o-obiegu-zamknietym-bez-odpadow-i-bez-zludzen,123100.html.

Wiśniewski, Grzegorz, Magdalena Ligus, Katarzyna Michałowska-Knap, i Aleksandra Arcipowska. 2012. Morski wiatr kontra atom. Analiza porównawcza kosztów morskiej energetyki wiatrowej i energetyki jadrowej oraz ich potencjatu tworzenia miejsc pracy. Warszawa: Greenpeace Polska i Fundacja im. Heinricha Bölla. 